https://doi.org/10.18778/1509-877X.2020.03.02

\title{
PRZESŁANKI DOPUSZCZALNOŚCI INGERENCJI MDR W TAJEMNICE DORADCY PODATKOWEGO W KONTEKŚCIE ORZECZNICTWA TRYBUNAŁU SPRAWIEDLIWOŚCI UNII EUROPEJSKIEJ i Europejskiego TrybunaŁu Praw CzŁowieka
}

Streszczenie. Artykuł koncentruje się na problemie zagrożeń dla tajemnicy zawodów prawniczych wynikających z MDR. Niemniej konflikt ten został już przynajmniej częściowo rozwiązany w przypadku regulacji dotyczących przeciwdziałania praniu pieniędzy i finansowaniu terroryzmu (AML). W tekście omówiono, w jaki sposób reguła AML może być stosowana jako minimalny standard proporcjonalności w przypadkach MDR. Zakładając, że motywy regulacji AML są ważniejsze społecznie niż regulacji MDR, należy rozważyć, czy regulacje MDR nie powinny być poddane silniejszym filtrom. Korzystając z praktyki orzeczniczej wypracowanej przez ETPC i TSUE, dokonano próby ustalenia prawdopodobnego standardu ochrony tajemnicy zawodowej.

Słowa kluczowe: raportowanie schematów podatkowych, prawa człowieka, Trybunał Sprawiedliwości Unii Europejskiej, Europejski Trybunał Praw Człowieka, przeciwdziałanie praniu pieniędzy, proporcjonalność, tajemnica zawodowa zawodów prawniczych

* Doktorant w Szkole Doktorskiej Nauk Społecznych Uniwersytetu Łódzkiego, e-mail: adam.szymacha88@gmail.com,https://orcid.org/0000-0002-9372-9647 
W artykule podjęto próbę ustalenia przesłanek proporcjonalności zastosowania wyłączenia tajemnicy zawodowej w przypadku obowiązków MDR (Mandatory Disclosure Rules), opierając się na orzecznictwie Trybunału Sprawiedliwości Unii Europejskiej (TSUE) i Europejskiego Trybunału Praw Człowieka (ETPC). Kwestie kontrowersji o naturze konstytucyjnej, związanych z przepisami wprowadzającymi obowiązek raportowania schematów podatkowych, zostały już poruszone przez A. Mariańskiego i A. Michalak ${ }^{1}$. Główne zarzuty pod adresem norm MDR to niedostateczna precyzja i niedookreśloność regulacji oraz nieproporcjonalność i nadmierna represyjność norm ustanawiających obowiązek raportowania schematów podatkowych. Zauważono też, że tajemnica prawnie chroniona jest nie tylko obowiązkiem doradcy podatkowego, lecz także powinna być jego podstawowym prawem i przywilejem wobec osób trzecich i władz publicznych ${ }^{2}$. Nie ulega wątpliwości, że ograniczenie tajemnicy zawodowej zagraża prawom fundamentalnym, lecz niestety brak orzecznictwa wprost odnoszącego się do obowiązkowego raportowania schematów podatkowych. Istnieją natomiast orzeczenia pozwalające $\mathrm{z}$ dużym prawdopodobieństwem przewidywać stanowiska obu tych trybunałów w przyszłości.

Ustawodawca, wprowadzając rozdział 11a Ordynacji podatkowej33, w którym zawarte są regulacje MDR, ustanowił właściwie nieograniczony obowiązek raportowania schematów podatkowych. Zakres obowiązków wykracza daleko poza potrzebę walki z planowaniem podatkowym, a jednym z bardziej kontrowersyjnych elementów tej regulacji jest stworzenie fikcji prawnej, zgodnie z którą przekazanie określonych informacji o schemacie podatkowym nie stanowi naruszenia obowiązku zachowania tajemnicy zawodów prawniczych ${ }^{4}$.

Regulacje ustanawiające obowiązek raportowania schematów podatkowych zawarte w rozdziale 11a o.p. stanowią transpozycję dyrektywy

1 A. Mariański, A. Michalak, Wprowadzenie obowiązku raportowania schematów podatkowych. Analiza prawno-konstytucyjna, „Przegląd Podatkowy” 2020, nr 8(352).

2 Ibidem, s. 37.

3 Ustawa z dnia 29 sierpnia 1997 r. Ordynacja podatkowa (tekst jedn. Dz.U. z 2020 r., poz. 1325), dalej: o.p.

${ }^{4}$ Uchwała Nr 618/2019 Krajowej Rady Doradców Podatkowych z dnia 17 grudnia 2019 r. w sprawie wystąpienia do Trybunału Konstytucyjnego z wnioskiem o zbadanie zgodności ustawy z Konstytucją (Lex Podat. 2019.12.17). 
Rady Unii Europejskiej 2018/8225 zmieniającej dyrektywę 2011/16/UE w zakresie obowiązkowej, automatycznej wymiany informacji w dziedzinie opodatkowania, w odniesieniu do podlegających zgłoszeniu uzgodnień transgranicznych ${ }^{6}$. Rozwiązania zawarte $\mathrm{w}$ dyrektywie polegają na obowiązku raportowania uzgodnień, których głównym lub jedynym celem jest korzyść podatkowa. Dyrektywa nakazuje też państwom członkowskim wprowadzenie skutecznych i odstraszających sankcji w razie uchybienia obowiązkom sprawozdawczym ${ }^{7}$. W celu implementacji tego postanowienia, ustawodawca wprowadził art. 80f Kodeksu karnego skarbowego ${ }^{8}$, zgodnie z którym osoby uchybiające obowiązkom sprawozdawczym podlegają karze grzywny do 720 stawek dziennych.

Polski prawodawca wprowadził pojęcie korzystającego ${ }^{9}$, które wykracza poza zakres desygnatu podatnika ${ }^{10}$. Zgodnie $z$ treścią art. 86A $₫ 1$ pkt 3 o.p. korzystającym jest osoba fizyczna, osoba prawna lub jednostka

5 Dyrektywa Rady(UE) 2018/822 z dnia 25 maja 2018 r. (Dz. Urz. UE L 139/1 z dnia 25 maja 2018 r.), dalej: Dyrektywa.

6 Ibidem, motyw 2.

7 Ibidem, motyw 15.

8 Ustawa z dnia 10 września 1999 r. Kodeks karny skarbowy (tekst jedn. Dz.U. z 2021 r., poz. 408), dalej: k.k.s.

9 Ordynacja podatkowa wyróżnia korzystającego, promotora i wspomagającego. W dyrektywie 822/2018 posłużono się pojęciem „pośrednik” (art. 1 ust. 1 pkt 21 Dyrektywy). Polski ustawodawca postanowił stworzyć w to miejsce dwie instytucje, czyli promotora i wspomagającego. Zgodnie z art. 86a $\$ 1$ pkt 3 o.p. promotorem jest osoba fizyczna, osoba prawna lub jednostka organizacyjna niemająca osobowości prawnej, w szczególności doradca podatkowy, adwokat, radca prawny, pracownik banku lub innej instytucji finansowej doradzający klientom, również w przypadku gdy podmiot ten nie posiada miejsca zamieszkania, siedziby ani zarządu na terytorium kraju, która opracowuje, oferuje, udostępnia lub wdraża uzgodnienie lub zarządza wdrażaniem uzgodnienia. Wspomagający to osoba fizyczna, osoba prawna lub jednostka organizacyjna nieposiadająca osobowości prawnej, w szczególności biegły rewident, notariusz, osoba świadcząca usługi prowadzenia ksiąg rachunkowych, księgowy lub dyrektor finansowy, bank lub inna instytucja finansowa, a także ich pracownik, która przy zachowaniu staranności ogólnie wymaganej w dokonywanych czynnościach, przy uwzględnieniu zawodowego charakteru działalności, obszaru specjalizacji oraz przedmiotu wykonywanych czynności, podjęła się udzielić, bezpośrednio lub za pośrednictwem innych osób, pomocy, wsparcia lub porad dotyczących opracowania, wprowadzenia do obrotu, organizowania, udostępnienia do wdrożenia lub nadzorowania wdrożenia uzgodnienia (art. 86a $\$ 1$ pkt 3 i 18 o.p.).

10 D.M. Malinowski, Dyrektywa 2018/822 - zasady przekazywania informacji o uzgodnieniach transgranicznych $i$ ich skutkach podatkowych, "Przegląd Podatkowy” 2018, nr 8, s. 4. 
organizacyjna niemająca osobowości prawnej, której zgodnie z art. 86a $₫ 1$ pkt 3 o.p. udostępniane jest lub u której wdrażane jest uzgodnienie, lub która jest przygotowana do wdrożenia uzgodnienia lub dokonała czynności służącej wdrożeniu takiego uzgodnienia. Według objaśnień podatkowych korzystającym $\mathrm{z}$ reguły będzie podatnik ${ }^{11}$. $\mathrm{Z}$ tego względu $\mathrm{w}$ dalszej części artykułu używane będzie pojęcie "podatnik”.

Co do zasady zobowiązany do raportowania jest promotor, czyli w praktyce przedstawiciel zawodu prawniczego, np. adwokat bądź doradca podatkowy. Chodziło o szerokie ujęcie podmiotów tworzących abstrakcyjne schematy podatkowe, które mogą być wykorzystane przy agresywnym planowaniu podatkowym ${ }^{12}$. Możliwe jednak, że to korzystający będzie zobowiązany do przekazania informacji o schemacie podatkowym. Będzie tak w przypadku braku promotora albo gdy promotor nie zostanie zwolniony $\mathrm{z}$ tajemnicy zawodowej (art. $86 \mathrm{~b} \$ 4$ o.p.).

Liczne kontrowersje dotyczące bardzo inwazyjnych wobec praw podatników regulacji MDR znalazły swoje odzwierciedlenie we wniosku do Trybunału Konstytucyjnego sporządzonego przez Krajową Izbę Doradców Podatkowych. Podnoszono w nim wielokrotne naruszenie zasady państwa prawnego, m.in. poprzez uniemożliwienie samorządom zawodowym rzetelnego i sprawnego działania, ograniczenie prawa do sądu (art. 86b $\$ 4$ poz. D o.p.), a także naruszenie zasady zaufania do państwa i stanowionego przez nie prawa, zasady poprawnej legislacji i zasady zachowania odpowiedniego vacatio legis (art. $86 \mathrm{~b} \$ 4$ poz. B o.p.). Wśród zarzutów znalazło się też ustanowienie obowiązku naruszenia tajemnicy zawodowej przez doradcę podatkowego (art. $86 \mathrm{~b} \$ 4$ poz. A o.p.).

Obowiązek zachowania tajemnicy zawodowej w postępowaniach sądowych dotyczy właściwie trzech grup zawodowych. Są to adwokaci, radcy prawni i doradcy podatkowi. Ze względu na to, że z przepisami MDR mają styczność głównie ci ostatni, w dalszej części artykułu będzie mowa o doradcach podatkowych lub o prawnikach.

Zgodnie z zasadami etyki doradców podatkowych przedstawiciel tej grupy zawodowej ma obowiązek zachować w tajemnicy wszelkie fakty

11 Objaśnienia podatkowe: informacje o schematach podatkowych (MDR), s. 37, https://www.podatki.gov.pl/media/4417/obja\%C5\%9Bnienia-podatkowe-mdr-zdnia-31-01-2019.pdf (dostęp: 20.07.2021).

12 Ordynacja podatkowa. Komentarz, red. H. Dzwonkowski, wyd. 9, Rozdział 11a, Legalis/el. 
i informacje, jakie powziął w związku z wykonywaniem zawodu. Obowiązek ten jest nieograniczony czasowo ${ }^{13}$.

Tajemnica zawodów prawniczych stanowi element prawa do sądu oraz prawa do prywatności. Oba te prawa fundamentalne są chronione na gruncie Karty Praw Podstawowych (KPP) oraz Europejskiej Konwencji Praw Człowieka (EKPC). Prawo do poufności komunikacji pomiędzy przedstawicielem zawodu prawniczego a jego klientem, będące jednym $\mathrm{z}$ elementów prawa do prywatności, znalazło odbicie w art. 7 i $47 \mathrm{KPP}$ oraz art. 6 i $8 \mathrm{EKPC}^{14}$. Z kolei prawo do skutecznego środka ochrony sądowej wyrażone zostało w art. $47 \mathrm{KPP}$ i art. 6 EKPC. Polega ono na przywileju prawniczym (legal professional privilege), czyli możliwości nieujawniania treści kontaktów między adwokatem a jego klientem ${ }^{15}$. Tajemnica chroni obywateli przed pochopnym wyjawieniem informacji, które mogłoby naruszać ich integralność moralną oraz ich dobre imię ${ }^{16}$, i służy w ten sposób prawidłowemu funkcjonowaniu wymiaru sprawiedliwości ${ }^{17}$. Umożliwia ona

${ }^{13}$ Artykuły 6 i 7 Zasad etyki doradców podatkowych, Załącznik do uchwały nr 237/2018 Krajowej Rady Doradców Podatkowych z dnia 22 maja 2018 r. w sprawie przyjęcia tekstu jednolitego Zasad etyki doradców podatkowych; art. 37 ust. 1a Ustawy z dnia 5 lipca 1996 r. o doradztwie podatkowym (tekst jedn. Dz.U. z 2016 r., poz. 794).

${ }^{14}$ Artykuł 7 KPP: „Każdy ma prawo do poszanowania życia prywatnego i rodzinnego, domu i komunikowania się”. Artykuł 47 KPP: „Każdy, kogo prawa i wolności zagwarantowane przez prawo Unii zostały naruszone, ma prawo do skutecznego środka prawnego przed sądem, zgodnie z warunkami przewidzianymi w niniejszym artykule. Każdy ma prawo do sprawiedliwego $i$ jawnego rozpatrzenia jego sprawy w rozsądnym terminie przez niezawisły i bezstronny sąd ustanowiony uprzednio na mocy ustawy. Każdy ma możliwość uzyskania porady prawnej, skorzystania z pomocy obrońcy i przedstawiciela. Pomoc prawna jest udzielana osobom, które nie posiadają wystarczających środków, $\mathrm{w}$ zakresie, $w$ jakim jest ona konieczna dla zapewnienia skutecznego dostępu do wymiaru sprawiedliwości" (Dz. Urz. UE C 326/391 z dnia 7 grudnia 2000 r.). Artykuł 6 ust. 1 EKPC: „Każdy ma prawo do sprawiedliwego i publicznego rozpatrzenia jego sprawy w rozsądnym terminie przez niezawisły i bezstronny sąd ustanowiony ustawą przy rozstrzyganiu o jego prawach i obowiązkach o charakterze cywilnym albo o zasadności każdego oskarżenia w wytoczonej przeciwko niemu sprawie karnej”. Artykuł 8 ust. 1 EKPC: „Każdy ma prawo do poszanowania swojego życia prywatnego i rodzinnego, swojego mieszkania i swojej korespondencji” (Dz.U. z 1993 r., Nr 61, poz. 284).

${ }_{15}$ K. Kowalik-Bańczyk, Prawo do obrony w unijnych postępowaniach antymonopolowych. W kierunku unifikacji standardów proceduralnych $w$ Unii Europejskiej, Warszawa 2012, s. 389-390.

${ }^{16}$ C-305/05 Ordre des barreaux francophones et germanophone przeciwko Conseil des ministres, Opinia Rzecznika Generalnego (ECLI:EU:C:2006:788, poz. 41).

${ }_{17}$ Ibidem, poz. 54. 
zatem realizację skutecznego środka prawnego przed sądem ${ }^{18}$. Tajemnica zawodowa chroni przede wszystkim prawa klienta ${ }^{19}$.

Aby uniknąć konfliktu obowiązków MDR z obowiązkiem zachowania tajemnicy zawodowej, stworzono przepis $86 \mathrm{~b} \$ 7$ o.p., zgodnie z którym nie stanowi naruszenia obowiązku zachowania prawnie chronionej tajemnicy zawodowej:

1. przekazanie informacji o schemacie podatkowym w sytuacji, w której przekazujący tę informację został zwolniony z obowiązku jej zachowania; 2. przekazanie informacji o schemacie podatkowym standaryzowanym; 3. przesłanie do Szefa Krajowej Administracji Skarbowej informacji, o której mowa w $\$ 6$.

Takie wyłączenie tajemnicy zawodowej, szczególnie w kwestiach podatkowych, wywołało dyskusję na temat możliwych przesłanek proporcjonalności tego rozwiązania. W doktrynie zauważono, że nie może wiązać doradcy podatkowego oświadczenie klienta o zwolnieniu z tajemnicy prawnie chronionej. Jest bezskuteczne, gdyż obowiązek etyczny i ustawowy ma pierwszeństwo ${ }^{20}$. Do 2019 r. znane były w zasadzie dwa przypadki możliwości odstąpienia od obowiązku zachowania tajemnicy prawnie chronionej. Pierwszym $z$ nich jest art. $180 \$ 2$ Kodeksu postępowania karnego ${ }^{21}$, zgodnie z którym z tajemnicy zawodowej zwolnić może jedynie sąd, „gdy jest to niezbędne dla dobra wymiaru sprawiedliwości, a okoliczność nie może być ustalona na podstawie innego dowodu". Odstępstwo od ochrony tajemnicy zawodowej ma charakter wyjątkowy. Nawet jednak ono jest krytykowane w doktrynie jako godzące w dobro wymiaru sprawiedliwości, gdyż nie tylko wyrok powinien być sprawiedliwy, ale także sam sposób dojścia do niego ${ }^{22}$. Warto zauważyć, że brak podobnych regulacji na gruncie innych postępowań, a tym bardziej na gruncie Ordynacji podatkowej²3.

${ }^{18}$ Ibidem, poz. 60.

19 M. Matusiak-Frącczak, Przyszłość tajemnicy adwokackiej w Polsce, [w:] Perspektywy rozwoju samorządów prawniczych, red. P. Rączka, K. Rokicka-Murszewska, Toruń 2020, s. 73.

20 A. Mariański, A. Michalak, Wprowadzenie obowiązku raportowania schematów podatkowych..., s. 37 .

${ }^{21}$ Ustawa z dnia 6 czerwca 1997 r. - Kodeks postępowania karnego (Dz.U. z 1997 r., Nr 89, poz. 555).

22 M. Matusiak-Frącczak, Przyszłość tajemnicy adwokackiej..., s. 77.

${ }_{23}$ M. Wilk, Ujawnianie schematów podatkowych a tajemnica zawodowa doradcy podatkowego, „Przegląd Podatkowy” 2019, nr 2, s. 18. 
Drugim przypadkiem uchylenia zasady poufności relacji pomiędzy prawnikiem a jego klientem są przepisy o przeciwdziałaniu praniu pieniędzy oraz finansowaniu terroryzmu ${ }^{24}$ (Anti Money Laundering - AML). Konstrukcja tych przepisów posłużyła za wzór dla obowiązków MDR ${ }^{25}$. Rozwiązania zawarte w dyrektywie AML z 2005 r. ${ }^{26}$ posługują się podobnym mechanizmem do tego, który został wprowadzony w przepisach MDR. Standard ustanowiony przez orzecznictwo dotyczące przepisów $\mathrm{AML}^{27}$ może per analogiam posłużyć do przybliżenia ewentualnego minimalnego standardu w przypadku regulacji MDR.

\section{WYrok C-305/05 I OpINIA RZECZNIKA GENERALNEGO}

W wyroku TSUE w sprawie Ordre des barreaux francophones et germanophone ${ }^{28}$, w którym badano zgodność przepisów o przeciwdziałaniu praniu pieniędzy i finansowaniu terroryzmu z prawem do rzetelnego procesu, zastosowano konkretne kryteria dopuszczalności wyłączenia tajemnicy zawodowej, tzn. przyzwolono na wyłączenie co do czynności biznesowych niestanowiących istoty zawodów prawniczych ${ }^{29}$.

Temat naruszenia prawa do prywatności został natomiast rozwinięty przez Rzecznika Generalnego TSUE M. Poiaresa Maduro. W swojej opinii zaproponował Trybunałowi metodologię określania granicy kluczowych pojęć. Zgodnie z nią na ochronę zasługiwałyby te czynności, które stanowią istotę zawodu adwokata, w szczególności związane z postępowaniem i udzielaniem porad prawnych. Ochrona nie przysługiwałaby jednak, gdyby adwokat działał w charakterze „pośrednika biznesowego”. Pod pojęciem

${ }^{24}$ Ustawa $\mathrm{z}$ dnia 1 marca 2018 r. o przeciwdziałaniu praniu pieniędzy oraz finansowaniu terroryzmu (Dz.U. z 2018 r., poz. 723) implementująca Dyrektywę Parlamentu Europejskiego i Rady (UE) 2015/849 z dnia 20 maja 2015 r. w sprawie zapobiegania wykorzystywaniu systemu finansowego do prania pieniędzy lub finansowania terroryzmu (AML).

25 J. Rudowski, Rozdziat 11A. Informacje o schematach podatkowych, [w:] Ordynacja podatkowa. Komentarz, red. S. Babiarz, B. Dauter, R. Hauser, A. Kabat, M. Niezgódka-Medek, J. Rudowski, Warszawa 2019, s. 619.

${ }^{26}$ Ibidem.

27 A. Ploszka, Tajemnica zawodowa prawników a przeciwdziałanie praniu pieniędzy w kontekście dialogu trybunałów europejskich, [w:] Wpływ Europejskiej Konwencji Praw Człowieka na funkcjonowanie biznesu, red. A. Bodnar, A. Ploszka, Warszawa 2016, s. 114.

28 C-305/05 Ordre des barreaux francophones et germanophone przeciwko Conseil des Ministres (ECLI:EU:C:2007:383).

${ }^{29}$ Ibidem, poz. 33. 
tym rozumiane są takie sytuacje, w których prawnik podejmuje się „przeprowadzenia lub przygotowania transakcji handlowej lub finansowej oraz gdy klient udziela prawnikowi instrukcji”. W takich sytuacjach należy wyłączyć obowiązki informacyjne, zwłaszcza gdy porady prawne służą organizowaniu działalności zgodnie z prawem ${ }^{30}$.

Nie ulegało przy tym wątpliwości, że wzmocnionej ochronie podlega tajemnica związana $z$ reprezentacją i obroną klienta ${ }^{31}$. Sama dyrektywa AML rozszerza zakres tej ochrony na „ustalanie sytuacji prawnej klienta”. Najistotniejsze dla rozstrzygnięcia problemu okazało się zinterpretowanie tego pojęcia. Według rzecznika pojęcie to obejmuje także udzielanie porad prawnych, choćby ze względu na podstawowy wymóg dostępu do wymiaru sprawiedliwości.

W praktyce trudno oddzielić czynności polegające na reprezentowaniu i te związane $z$ doradzaniem ${ }^{32}$. Każdorazowy podział wpłynąłby z pewnością negatywnie na zaufanie między prawnikiem a jego klientem. Wynika $\mathrm{z}$ tego, że wyłączenie tajemnicy zawodowej w stosunku do porad prawnych byłoby naruszeniem właśnie jej istoty.

Jednocześnie istotne jest ustalenie kryterium wskazującego, które czynności stanowią istotę zawodów prawniczych, a które są zwykłymi czynnościami biznesowymi ${ }^{33}$. Wydaje się, że odpowiednim kryterium jest czynnik niezależności w relacjach z klientem. O ile bowiem prawnik przedstawia klientowi stan prawny oraz dokonuje jego oceny w celu organizowania jego działalności zgodnie z prawem, nie powinien podlegać obowiązkowi raportowania. Inaczej jest, gdy prawnik dokonuje oceny stanu prawnego w celu przeprowadzenia transakcji, lecz to jego klient daje instrukcje, jakie kierunki działania obrać ${ }^{34}$. Rzecznik zaproponował stosowanie domniemania działania prawnika w charakterze doradcy prawnego ${ }^{35}$.

30 Rzecznik Generalny M. Poiares Maduro, Opinia w sprawie C-305/05 Ordre des barreaux francophones et germanophone przeciwko Conseil des ministres, poz. 73.

${ }^{31}$ Ibidem, poz. 55.

${ }^{32}$ Ibidem, poz. 61.

${ }^{33}$ Ibidem, poz. 65.

${ }^{34}$ Ibidem, poz. 70.

35 Ibidem, poz. 72. 
Podobną sprawą zajął się kilka lat później ETPC w orzeczeniu $M i$ chaud $^{36}$. Na wniosek francuskiego adwokata Patricka Michauda Trybunał zbadał, czy przepisy AML nie ingerują nieproporcjonalnie w tajemnicę zawodów prawniczych.

Trybunał uznał, że przepisy o zwalczaniu terroryzmu nie naruszają prawa do prywatności w kontekście szczególnej ochrony komunikacji między prawnikami a ich klientami. Jednym z czynników, który zaważył na takim stanowisku, było istnienie filtra chroniącego tajemnicę zawodową, w postaci wyznaczenia organu samorządu zawodowego jako właściwego do odbierania raportów. W omawianym przypadku pojawiły się dwa takie organy: prezes Adwokatury przy Radzie Stanu i Sądzie Kasacyjnym oraz dziekan Izby Adwokackiej. Zauważono, że organy te, będąc w istocie przedstawicielami tego samego zawodu i powołane do stania na straży tajemnicy zawodowej, dają wystarczającą rękojmię zachowania istoty tajemnicy zawodowej. Mechanizm wdrożony we Francji został bowiem tak skonstruowany, aby organy te przekazywały administracji rządowej jedynie takie informacje, co do których mają pewność, że ich przekazanie nie stanowi naruszenia tajemnicy prawnie chronionej ${ }^{37}$. W polskiej ustawie AML brak takich instytucji. Podejrzenia popełnienia przestępstwa muszą być raportowane wprost do Generalnego Inspektora Informacji Finansowej (GIIF).

Drugą okolicznością przesądzającą o tym, że francuskie przepisy AML nie stanowią nieproporcjonalnej ingerencji w szczególnie chronione prawo tajemnicy zawodowej, było ograniczenie obowiązku sprawozdawczego do dwóch przypadków. Pierwszy dotyczy sytuacji, w której prawnicy w ramach działalności zawodowej uczestniczą w transakcjach związanych z nieruchomościami w imieniu i na rzecz swoich klientów lub gdy działają jako powiernicy. Drugi odnosi się do pewnych kategorii operacji finansowych i majątkowych. Podsumowując, Trybunał uznał raportowanie o podejrzeniu popełnienia przestępstwa za zgodne z prawem, o ile nie dotyka istoty działalności adwokata ${ }^{38}$.

\footnotetext{
36 Skarga nr 12323/11, Michaud przeciwko Francji.

37 Ibidem, poz. 129.

38 Ibidem, poz. 127-128.
} 


\section{OCENA ORZECZEŃ W KONTEKŚCIE MDR}

Z kryterium zaproponowanego przez M. Poiaresa Maduro można wysnuć wniosek, że nie powinny podlegać raportowaniu schematy podatkowe standaryzowane ani żadne uzgodnienia opierające się na powszechnie uznanych narzędziach prawnych. Właściwe byłoby wyłączenie raportowania w stosunku do wszelkich czynności doradców podatkowych, o ile nie wiążą się z istnieniem sztucznych struktur lub czynności ekonomicznie nieuzasadnionych ${ }^{39}$.

M. Wilk ${ }^{40}$ przedstawił podobną koncepcję. Odwołując się do klauzuli $\mathrm{GAAR}^{41}$, zaproponował, aby obowiązki MDR oprzeć na przesłance sztuczności ${ }^{42}$, tak aby zachować zasadę proporcjonalności. Zgodnie $\mathrm{z}$ art. 119a o.p. czynność nie skutkuje osiągnięciem korzyści podatkowej, jeżeli korzyść ta jest sprzeczna z przedmiotem lub celem ustawy, czynność została dokonana głównie dla osiągnięcia tej korzyści, a sposób działania jest sztuczny. Artykuł 119c ustala więc kryteria oceny sztuczności operacji, opierając się na podstawach ekonomicznych, jakimi kierowałby się zgodnie z prawem podmiot działający rozsądnie.

Wydaje się, że ustawodawca również próbował nawiązać do podobnej koncepcji, na co może wskazywać konstrukcja kryterium głównej korzyści. Podobnie jak w przypadku klauzuli GAAR, kryterium to zestawia uzyskaną korzyść podatkową z podmiotem działającym rozsądnie i kierującym się zgodnym z prawem celem, który mógłby wybrać inny sposób postępowania. W takim przypadku korzyść podatkowa jest motorem uzgodnienia. Można powiedzieć, że w przepisach MDR posłużono się podobnymi zwrotami, chociaż sformułowano je mniej przejrzyście. Zabrakło jednak w definicji głównej korzyści elementu uzasadnienia ekonomicznego oraz nawiązania do sprzeczności uzgodnienia z przedmiotem i celem ustawy.

39 Przesłanka czynności „ekonomicznie nieuzasadnionych” jest konstrukcją prawnopodatkową. W nauce ekonomii istnieje teoria istotności struktury kapitału, zgodnie z którą obciążenia podatkowe mają istotny wpływ na decyzje przedsiębiorstw.

40 143. Konferencja Podatkowa „Unikanie opodatkowania w polskim systemie prawa podatkowego. Perspektywa konstytucyjna” organizowana przez Centrum Dokumentacji i Studiów Podatkowych Uniwersytetu Łódzkiego z dnia 10-11 grudnia 2019.

${ }^{41}$ Klauzula generalna obejścia prawa podatkowego z art. 119A o.p. (General Anti-Avoidance Rules).

${ }^{42}$ M. Wilk zaprezentował tezę o racjonalności powiązania obowiązków MDR z przesłanką sztuczności (sztucznej struktury), która mogłaby być zapożyczona z klauzuli GAAR. Teza zaprezentowana na Konferencji nie została dotąd opublikowana. 
Chociaż użyto częściowo tych samych elementów składowych determinujących raportowanie schematów podatkowych, to nieuwzględnienie ich wszystkich może wywierać inne skutki prawne. Projektodawcy podali w uzasadnieniu, że mowa o raportowaniu każdego działania dokonanego z pobudek podatkowych, nawet jeżeli wynika z uzasadnionych przyczyn ekonomicznych ${ }^{43}$. Jest to wykładnia spójna z treścią objaśnień podatkowych, w których wskazano, że jeżeli dany cel ekonomiczny może być osiągnięty na różne sposoby, a podmiot wybierze ten korzystniejszy podatkowo, to będzie to podlegać raportowaniu ${ }^{44}$. Nie tylko jednak zła konstrukcja kryterium głównej korzyści stanowi przeszkodę dla powiązania raportowania ze sztucznością. Nawet gdyby ustawodawca dopasował brzmienie tego przepisu do klauzuli GAAR, to dla schematu podatkowego ma to znaczenie tylko o tyle, o ile uzgodnienie ma ogólną cechę rozpoznawczą. Jeżeli natomiast ma szczególną bądź inną szczególną cechę rozpoznawczą, to nie wymaga się od takiego uzgodnienia spełnienia dodatkowego kryterium głównej korzyści dla obowiązku raportowania.

Podobnie jak w przepisach MDR, ustalono krąg instytucji obowiązanych do raportowania odpowiednim instytucjom informacji, przewidzianych przez ustawę oraz do współpracy z Generalnym Inspektorem Informacji Finansowej (GIIF). Instytucjami obowiązanymi są przedstawiciele zawodów prawniczych, złagodzono jednak obowiązek zawiadomienia GIIF o okolicznościach, które mogą wskazywać na podejrzenie popełnienia przestępstwa. Powinność ta nie dotyczy bowiem prawników w zakresie informacji uzyskanych podczas ustalania sytuacji prawnej klienta w związku z postępowaniem sądowym lub udzielania porady prawnej związanej z wszczęciem bądź uniknięciem wszczęcia postępowania sądowego ${ }^{45}$. Warto w tym miejscu zaznaczyć, że taki złagodzony rygor dla zawodów zaufania publicznego nie znalazł się w polskiej regulacji MDR. Tylko w załączniku do objaśnień podatkowych zawarto informację o podobnym brzmieniu,

${ }^{43}$ M. Wilk, Ujawnianie schematów podatkowych..., s. 19.

${ }^{44}$ Objaśnienia podatkowe: informacje..., s. 20 in fine.

45 Artykuł 75 Ustawy o przeciwdziałaniu praniu pieniędzy oraz finansowaniu terroryzmu: „Obowiązek przekazywania informacji i zawiadomień [...] nie dotyczy instytucji obowiązanych, o których mowa w art. 2 ust. 1 pkt 14, w zakresie informacji uzyskanych podczas ustalania sytuacji prawnej klienta w związku z postępowaniem sądowym, wykonywaniem obowiązków polegających na obronie, reprezentowaniu lub zastępowaniu klienta w postępowaniu sądowym albo udzielaniu klientowi porady prawnej dotyczącej wszczęcia postępowania sądowego lub uniknięcia takiego postępowania, niezależnie od czasu uzyskania tych informacji”. 
nie można jednak przejść obojętnie obok tego, że objaśnienia mają znacznie słabszą moc prawną niż ustawa ${ }^{46}$.

Jeszcze na etapie prac legislacyjnych Krajowa Rada Doradców Podatkowych (KRDP) opublikowała stanowisko, w którym wskazała na zagrożenia dla tajemnicy zawodowej" ${ }^{47}$ m.in. w postaci ogólnej cechy rozpoznawczej polegającej na ustanowieniu pomiędzy doradcą a jego klientem postanowień o poufności. Jak słusznie zauważyła KRDP, „zawarcie w umowie/uzgodnieniu klauzuli poufności wynika z istoty zawodu zaufania publicznego, jako że to właśnie pełna poufność umożliwia przekazanie przez klienta przedstawicielowi danego zawodu zaufania publicznego wszelkich informacji w celu wypracowania przez doradcę najodpowiedniejszych dla klienta rozwiązań zgodnych z obowiązującym prawem" ${ }^{48}$. Do tego zarzutu ustawodawca odniósł się w objaśnieniach podatkowych ${ }^{49}$. Zgodnie z wykładnią autentyczną tam zawartą klauzula poufności nie dotyczy ani tajemnicy zawodowej, ani handlowej. Dotyczy natomiast zachowania poufności w stosunku do osób trzecich w zakresie sposobu osiągnięcia korzyści podatkowych. Innymi słowy, poufność w znaczeniu MDR dotyczy utrzymania tajemnicy przedsiębiorstwa odnoszącej się do nowego produktu. Objaśnienia posługują się tutaj określeniem „innowacyjny” wobec takiego uzgodnienia. W celu zachowania przewagi nad konkurencją niezbędne jest utrzymanie struktury produktu w tajemnicy.

Jedną z zaproponowanych przez Poiaresa Maduro przesłanek dopuszczalności ingerencji w tajemnicę zawodów prawniczych jest brak swobody prawnika przy wykonywaniu czynności, określony jako „udzielanie przez klienta instrukcji”. Rzeczywiście, praca wykonywana przy stosowaniu się do ścisłych wytycznych udzielonych przez klienta nie jest cechą charakterystyczną wolnego zawodu prawniczego, jakim jest doradca podatkowy. Zgodnie $\mathrm{z}$ art. 5 ust. 1 Zasad etyki doradców podatkowych „Doradca podatkowy wykonuje zawód w sposób niezależny. W swoich decyzjach podlega jedynie przepisom prawa i zasadom etyki doradców podatkowych”. Dodatkowo według art. 4 ust. 1 Zasad etyki „Doradca podatkowy wykonuje czynności zawodowe według najlepszej woli i wiedzy, w sposób rzetelny,

46 Objaśnienia podatkowe: informacje..., s. 102, pkt 10.

47 Krajowa Rada Doradców Podatkowych przyjęła stanowisko w sprawie tajemnicy zawodowej w projekcie zmian w Ordynacji Podatkowej, https://kidp.pl/strona.php/2717 (dostęp: 8.03.2021).

48 Ibidem, pkt 1.

49 Objaśnienia podatkowe: informacje..., s. 68. 
z zachowaniem należytej staranności” ${ }^{50}$. Natomiast zgodnie z art. 31 ustawy o doradztwie podatkowym ${ }^{51}$ doradca podatkowy wprawdzie może być zatrudniony, ale ten stosunek pracy nie może naruszać jego niezależności i bezstronności, a także nie może pozostawać w sprzeczności z zasadami etyki zawodowej doradcy podatkowego.

Z przytoczonych przepisów wynika, że immanentną cechą wykonywania zawodu doradcy podatkowego jest niezależność. Tymczasem według Poiaresa Maduro może dojść do przełamania ochrony tajemnicy zawodów prawniczych w sytuacji, gdy doradca podatkowy nie wykonuje czynności związanych z istotą tego zawodu i nie jest niezależny. Są to przypadki, gdy doradca podatkowy przeprowadza lub przygotowuje transakcje handlowe lub finansowe. Tym samym nie wykonuje czynności prawniczych, do których wymagane są szczególne kompetencje, lecz wykonuje czynności, które mogłaby podjąć każda osoba. Warto także zwrócić uwagę, że przygotowywanie jakichkolwiek transakcji jest czynnością wtórną, polegającą na wykonywaniu prac już zaplanowanych. A contrario nie powinny podlegać raportowaniu wszelkie czynności cechujące się niezależnością, właściwe dla wolnego zawodu doradcy podatkowego.

5. Podsumowanie

Zgodnie z orzecznictwem TSUE i ETPC można określić następujące przesłanki proporcjonalności ingerencji w tajemnicę zawodową doradcy podatkowego:

- przesłanka formalna jako raportowanie schematu podatkowego wyznaczonemu organowi izby doradców podatkowych;

- raportowaniu powinny podlegać czynności biznesowe niestanowiące istoty zawodów prawniczych;

- z obowiązku raportowania powinny być bezwzględnie wyłączone czynności związane z postępowaniem sądowym i polegające na udzielaniu porad prawnych, w tym polegające na organizowaniu swojej działalności zgodnie z prawem;

50 Artykuł 4 ust. 1 i art. 5 ust. 1 Zasad etyki doradców podatkowych, Załącznik do uchwały nr 237/2018 Krajowej Rady Doradców Podatkowych z dnia 22 maja 2018 r. w sprawie przyjęcia tekstu jednolitego Zasad etyki doradców podatkowych, dalej: Zasady etyki.

51 Ustawa z dnia 5 lipca 1996 r. o doradztwie podatkowym (tekst jedn. Dz.U. z 2020 r., poz. 130), art. 31 ust. 2 i 3. 
- obowiązek sprawozdawczy powinien dotyczyć tych czynności, kiedy doradca podatkowy działa jako pośrednik biznesowy. Za takie należy uznać przeprowadzenie lub przygotowanie transakcji handlowej lub finansowej oraz sytuacje, gdy klient udziela prawnikowi instrukcji;

- $\quad$ z obowiązku sprawozdawczego powinny zostać wyłączone czynności związane z reprezentowaniem i obroną klienta;

- $\quad$ z obowiązków MDR należy zwolnić takie czynności, przy których doradca podatkowy zachowuje niezależność. Potrzebne byłoby też domniemanie niezależnego działania doradcy podatkowego. Takie kryterium zapewniłoby objęcie obowiązkiem sprawozdawczym jedynie działań o charakterze stricte optymalizacyjnym; należy powiązać obowiązek raportowania $\mathrm{z}$ kryterium sztuczności struktur, ewentualnie także z kryterium rozwiązań innowacyjnych i chronionych poufnością przed innymi podmiotami.

Ostatnia przesłanka jest przesłanką de lege ferenda, a wynika z wniosku, że raportowanie schematów podatkowych standaryzowanych nie ma aksjologicznego uzasadnienia, tym bardziej że ustawodawca ma pewne problemy z identyfikacją tej kategorii schematów. W uzasadnieniu do ustawy wprowadzającej MDR znalazł się przykład niegdysiejszej popularności prowadzenia działalności w formie spółki komandytowo-akcyjnej, dla zobrazowania schematu podatkowego ${ }^{52}$. Nie kwestionując faktu, że taka forma prowadzenia działalności gospodarczej była bardzo popularna do momentu objęcia jej podatkiem dochodowych od osób prawnych, należy stwierdzić, że trudno uznać spółkę komandytowo-akcyjną za przejaw agresywnego planowania podatkowego. Do 2014 r. spółka ta była transparentna podatkowo, nie można zatem uznać, że było to działanie sztuczne lub innowacyjne. Korzystanie przez podatników z legalnych i akceptowanych powszechnie narzędzi prawnych nie powinno być piętnowane.

\section{ZAKOŃCZENIE}

Na koniec warto zauważyć, że o ile pod pewnymi warunkami TSUE i ETPC dopuściły raportowanie w związku z przepisami AML, to jednak dotyczą one poważnych, trudnych do wykrycia i bardzo szkodliwych

52 Uzasadnienie do Rządowego projektu ustawy o zmianie ustawy o podatku dochodowym od osób fizycznych, ustawy o podatku dochodowym od osób prawnych, ustawy - Ordynacja podatkowa oraz niektórych innych ustaw, druk 2860, s. 98 i 100. 
społecznie przestępstw, natomiast raportowanie MDR dotyczy działań całkowicie legalnych, a niekiedy nawet społecznie akceptowanych lub obojętnych. Z tego względu należy uznać, że wymienione wyżej przesłanki proporcjonalności ingerencji w tajemnicę zawodową wyznaczają standard minimalnej ochrony i nie jest wykluczone, że późniejsze orzecznictwo ustanowi ochronę na wyższym poziomie.

Ze względu na to, że motywy społeczne przepisów MDR są znacznie mniej doniosłe, trzeba też zgodzić się ze stanowiskiem Rady Krajowej Izby Doradców Podatkowych, zgodnie z którym „korzystający powinien być podmiotem odpowiedzialnym za ostateczne dostarczenie raportu - częstokroć to tylko on dysponuje właściwymi informacjami na temat momentu i zakresu wdrożenia konkretnych rozwiązań, ostatecznego całościowego ich kształtu oraz wpływu na zobowiązanie podatkowe" ${ }^{53}$.

Przepisy dotyczące raportowania schematów podatkowych zostały uchwalone w wyniku transpozycji dyrektywy 2018/822. Zgodnie z motywem 18 dyrektywy jej przepisy pozostają w zgodzie z prawami fundamentalnymi ${ }^{54}$. Trudno uznać, że ciekawość administracji skarbowej jest wystarczającą przesłanką, aby usprawiedliwić głęboką ingerencję w prawo do sądu i do poufności korespondencji.

\section{Bibliografia}

Kowalik-Bańczyk K., Prawo do obrony w unijnych postępowaniach antymonopolowych. W kierunku unifikacji standardów proceduralnych w Unii Europejskiej, Warszawa 2012. Malinowski D.M., Dyrektywa 2018/822 - zasady przekazywania informacji o uzgodnieniach transgranicznych $i$ ich skutkach podatkowych, „Przegląd Podatkowy” 2018, nr 8.

Mariański A., Michalak A., Wprowadzenie obowiazku raportowania schematów podatkowych. Analiza prawno-konstytucyjna, „Przegląd Podatkowy” 2020, nr 8(352).

Matusiak-Frącczak M., Przyszłość tajemnicy adwokackiej w Polsce, [w:] Perspektywy rozwoju samorządów prawniczych, red. P. Rączka, K. Rokicka-Murszewska, Toruń 2020.

Ordynacja podatkowa. Komentarz, red. H. Dzwonkowski, wyd. 9, Legalis/el.

${ }^{53}$ Krajowa Rada Doradców Podatkowych przyjęła stanowisko w sprawie tajemnicy zawodowej $w$ kontekście obowiązku przekazywania informacji o schematach podatkowych, akapit 4, https://kidp.pl/strona.php/2833 (dostęp: 8.03.2021).

54 Motyw 18 Dyrektywy Rady UE 2018/822 z dnia 25 maja 2018 r.: „Niniejsza dyrektywa nie narusza praw podstawowych oraz jest zgodna $\mathrm{z}$ zasadami uznanymi w szczególności w Karcie praw podstawowych Unii Europejskiej” (Dz. Urz. UE L 139/1 z dnia 25 maja 2018 r.). 
Ploszka A., Tajemnica zawodowa prawników a przeciwdziałanie praniu pieniędzy w kontekście dialogu trybunałów europejskich, [w:] Wpływ Europejskiej Konwencji Praw Człowieka na funkcjonowanie biznesu, red. A. Bodnar, A. Ploszka, Warszawa 2016.

Rudowski J., Rozdziat 11A. Informacje o schematach podatkowych, [w:] Ordynacja podatkowa. Komentarz, red. S. Babiarz, B. Dauter, R. Hauser, A. Kabat, M. Niezgódka-Medek, J. Rudowski, Warszawa 2019.

Wilk M., Ujawnianie schematów podatkowych a tajemnica zawodowa doradcy podatkowego, „Przegląd Podatkowy” 2019, nr 2.

\section{THE RATIONALE FOR THE PERMISSIBILITY OF MDR'S INTERFERENCE WITH TAX ADVISOR CONFIDENTIALITY IN THE CONTEXT of THE CASE LAW OF THE Court of Justice of THE European Union and the European Court of Human Rights}

Summary. The article focuses on the problem of the threats to the legal professional privilege caused by MDR (Mandatory Disclosure Rules). Nevertheless, this conflict has already been solved in the cases of anti-money laundering and counter terrorism financing (AML) regulations. The article thus discusses how the AML rule can be applied to as the minimum standard of proportionality for MDR cases. Assuming the motives of AML regulations are more socially important than the MDR regulations it has to be considered whether the MDR regulations should face stronger filters. Using the practice of jurisprudence established by the ECHR and CJEU, Polish regulations and authentic interpretations on that topic will be reviewed.

Keywords: Mandatory Disclosure Rules, human rights, Court of Justice of the European Union, European Court of Human Rights, anti-money laundering, proportionality, legal professional privilege 